\title{
Erratum to: Terrestrial Sources Homogenize Bacterial Water Quality During Rainfall in Two Urbanized Watersheds in Santa Barbara, CA
}

\author{
Bram Sercu • Laurie C. Van De Werfhorst • \\ Jill L. S. Murray • Patricia A. Holden
}

Published online: 7 July 2011

(C) Springer Science+Business Media, LLC 2011

Erratum to: Microb Ecol

DOI 10.1007/s00248-011-9874-z

The original version of this article was not complete. The soil sampling locations were not included in the original Fig. 1. A corrected Fig. 1 is added with soil sampling locations indicated by open symbols. The correct version of the figure is shown here.

The online version of the original article can be found at http://dx.doi. org/10.1007/s00248-011-9874-z.

B. Sercu $\cdot$ L. C. Van De Werfhorst · P. A. Holden

Donald Bren School of Environmental Science and Management,

University of California,

Santa Barbara, CA 93106-5131, USA

B. Sercu $(\bowtie) \cdot$ L. C. Van De Werfhorst $\cdot$ P. A. Holden

Earth Research Institute, University of California,

Santa Barbara, CA 93106-3060, USA

e-mail: sbram@bren.ucsb.edu

\section{J. L. S. Murray}

City of Santa Barbara,

Creeks Restoration and Water Quality Improvement Division,

PO Box 1990, Santa Barbara, CA 93101, USA 

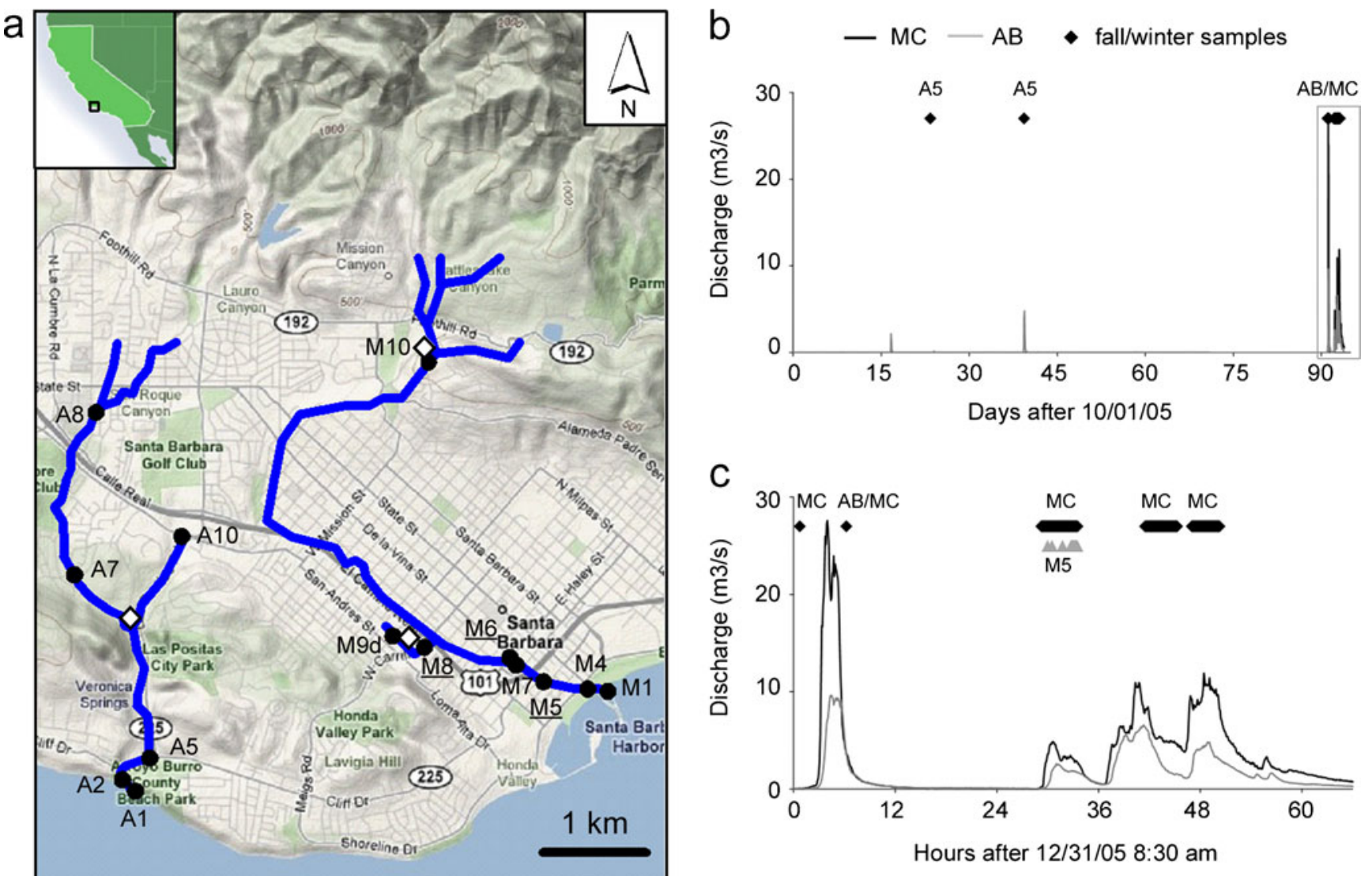